\title{
DOES ECONOMIC UPGRADING LEAD TO SOCIAL UPGRADING IN CONTACT CENTERS? EVIDENCE FROM SOUTH AFRICA.
}

\section{Mohammad Amir Anwar 1,2 Mark Graham ${ }^{1}$}

${ }^{1}$ Oxford Internet Institute, University of Oxford ${ }^{1,2}$ School of Tourism and Hospitality, University of Johannesburg

Mohammad.anwar@oii.ox.ac.uk Mark.graham@oii.ox.ac.uk

\section{This is a Pre-Publication Version}

This paper will be published in a forthcoming special issue on Geographies of Southern Africa in African Geographical Review.

Suggested citation:

Anwar, M. A. and Graham, M. (2019: forthcoming) Does economic upgrading lead to social upgrading in contact centers? Evidence from South Africa. African Geographical Review.

\section{Acknowledgments}

The authors would like thank Jamie Woodcock, Alex Wood, and David Sutcliffe for their extensive feedback on earlier drafts and anonymous referees for their comments. We are grateful to the European Research (ERC Grant Agreement n. 335716) for funding this work. 


\begin{abstract}
Business Process Outsourcing (BPO) has been identified by the South African government as a key driver of economic growth and employment generation. While BPO operations are inevitably tethered to some physical infrastructures, they can be relatively easily shifted around the world, threatening the jobs of current workers. This observation-combined with the industry's immense focus on workplace control and high levels of attrition-means that the development potential of the BPO industry on workers in South Africa is a matter of critical concern. This article uses the global production network (GPN) framework to understand the developmental potentials of contact center jobs for workers in South Africa. It asks under what conditions economic upgrading leads to the social upgrading and downgrading of workers in the context of outsourced services activities. One of the central arguments is that economic upgrading among BPO firms can lead to both social upgrading and downgrading among contact center workers. We end with some policy recommendations for the South African government.
\end{abstract}

Keywords: Global production networks, economic upgrading, social upgrading and downgrading, contact centers, South Africa

\title{
1. Introduction
}

Business Process Outsourcing (BPO) has been identified by the South African government as a key driver for economic growth and employment, with a number of initiatives (DTI, 2013, 2005) introduced to compete with dominant players in the industry like India and the Philippines (Pandy and Rogerson,_2014). These efforts are supported by recent studies that have asserted that South Africa is a viable BPO destination (Willcocks_et al..2 2015). Indeed, the South African BPO industry grew from an estimated 185 contact center operations in 1997 to well over a thousand by 2012 (Pandy and Rogerson 2014). ${ }^{1}$ In 2017, there were about 228,642 people employed in the sector, with just over 38,600 in its offshore segment (BPESA, 2018).

While these operations are inevitably tethered to some physical infrastructures, they can be relatively footloose, threatening jobs for potential workers (Beekman et al., 2004). This observation - combined with the industry's immense focus on workplace control and high levels of attrition (Taylor and Bain, 2005; Woodcock, 2016) - means that the development potential of these jobs for workers in South Africa is a matter of critical concern.

This article uses the global production network (GPN) framework to understand the development implications of contact center jobs in South Africa, especially on labor. ${ }^{2}$ Recently, GPN research has begun to examine how economic upgrading among firms leads to improvements in the socio-economic conditions of workers (i.e. social upgrading). While the link between economic upgrading and social upgrading has been studied through traditional economic activities such as garment manufacturing and horticulture in Africa, information economy activities have received less scholarly attention. We analyse this link by examining jobs in the South African BPO industry, concentrating on contact centers, as they are the largest BPO segment in South Africa in terms of persons employed.

We conducted a total of 34 in-depth interviews (Table 1) in Johannesburg, South Africa, between July and October 2016, including 16 workers from six different contact centers.

\footnotetext{
1 'Call center' is the term used by companies administering support services and information enquiries for its customers, primarily through voice calls. We prefer the term 'contact center' since non-voice interactions (emails, text messages, webchats) are becoming the norm in the outsourcing industry.

${ }^{2}$ We use the acronym GPN to denote theory or literature, and 'global production networks' to refer to the empirical phenomenon.
} 
Contacting workers proved to be difficult. In many cases, managers of firms refused us permission to speak to workers since they have privacy/confidentiality agreements with their end clients. Only one firm agreed to give us access to four of its workers. We, therefore, met other workers by developing contacts on social media and supplementing this strategy by meeting them in places where they are known to congregate, such as near street vendors outside contact centers. We attempted to speak with workers who had a range of experiences and backgrounds (Table 2). Our interviews focussed on workers' socio-economic backgrounds, employment history, current and previous work, economic and non-economic benefits, work-related physical and mental impacts, knowledge and skills development, and union membership. Worker names have been changed in this article to protect their identities.

We also interviewed 10 managers/executive officers of seven firms who were running contact centers in Johannesburg. Access to these firms also presented a challenge. A senior figure in one of the largest international BPO firms in South Africa cancelled our meeting twice; some spoke to us on condition of anonymity. Finally, we also conducted interviews with three industry experts, two members of a private sector association (Business Process Enabling South Africa (BPESA)), a member of a consulting firm, a member of a staffing agency, and a senior figure in the Department of Trade and Industry (DTI), responsible for its Business Process Services section.

Table 1: List of Interviews

\begin{tabular}{|l|l|l|}
\hline Category & $\underline{\text { Details }}$ & Total \\
\hline $\begin{array}{l}\text { Contact center } \\
\text { agents }\end{array}$ & $\begin{array}{l}13 \text { (Domestic firms); 3 (International } \\
\text { firms) }\end{array}$ & 16 \\
\hline Firms & 5 Domestic; 2 International & 10 \\
\hline BPESA & 2 & 2 \\
\hline Industry Experts & 3 & 3 \\
\hline Staffing Agency & 1 & 1 \\
\hline Consulting Firm & 1 & 1 \\
\hline $\begin{array}{l}\text { Government } \\
\text { official }\end{array}$ & 1 & 1 \\
\hline & Total & 34 \\
\hline
\end{tabular}

Table 2: Characteristics of Interviewed Workers

\begin{tabular}{|l|l|}
\hline Characteristics & $\mathrm{N}=16(\%)$ \\
\hline Gender & \\
\hline Male & $7(44)$ \\
\hline Female & $9(56)$ \\
\hline Education & \\
\hline Diploma or Matric (equivalent to UK's A Level) & $9(56)$ \\
\hline Undergraduate degree and above & $7(44)$ \\
\hline Age group & \\
\hline $18-24$ & $9(56)$ \\
\hline $25-29$ & $6(38)$ \\
\hline 30 and above & $1(6)$ \\
\hline Nature of work & \\
\hline Inbound (sales, technical support, customer service) & $13(81)$ \\
\hline Outbound $^{3}$ & $3(19)$ \\
\hline
\end{tabular}

${ }^{3}$ Both voice (calls) and non-voice services (email and web-chat). 
In the next section of this paper, we explore how economic development is understood within the GPN framework and why there is a need to focus on labour within GPN studies. Particular attention is drawn to the relative lack of understanding about the link between economic upgrading among firms and social upgrading of workers beyond the traditional sectors of the economy (i.e. manufacturing and agriculture). The third section then discusses upgrading in the South African outsourcing industry. Here the focus is on multiple upgrading trajectories and barriers to upgrading among local firms in the country. In the fourth section, we analyse how various economic upgrading trajectories impact social upgrading and downgrading among workers. The last section concludes with some reflections on what this means for workers who find jobs in contact centres, and outlines some policy recommendations.

\section{Production Networks and Economic Development}

The GPN framework has become a particularly useful explanatory tool for understanding the globalized nature of production in the $21^{\text {st }}$ century, utilising the concepts of power, value and embeddedness (Henderson et al., 2002). It traces its origin in the global value chain (GVC) and global commodity chain (GCC) approaches. According to Coe et al. (2008, p. 272) 'although the core of all three conceptualizations (GVC/GCC/GPN) is similar-the nexus of interconnected functions, operations and transactions through which a specific product or service is produced, distributed and consumed - there are two crucial differences, in practice, between GCCs/GVCs on the one hand and GPNs on the other'. Where the GVC approach employs a relatively linear understanding of the production process, the GPN framework incorporates a whole range of actors such as governments, multilateral organisations, and international trade unions, since they influence production activities through contested and often contradictory processes - including regulatory frameworks by states, ethical production codes/guidelines by international organisations such as the International Labor Organisation (ILO) and collective bargaining through labor unions.

One of the defining features of the GCC/GVC/GPN approaches is that they allow us to obtain insights into the process of economic development. Within the GVC literature, economic development is often understood through economic upgrading, i.e. firms moving into higher value, and more complex production is considered a high road to economic development (Barrientos et al., 2011; Gereffi, 2005). A firm can achieve four types of economic upgrading: process upgrading (efficient production through the use of improved technology), product upgrading (improving the quality of products), functional upgrading (introducing higher value-added activities), and chain upgrading (moving into different types of value

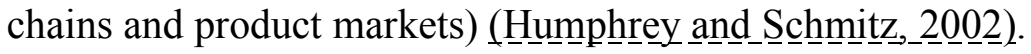

Despite economic upgrading (as a conceptual category) having its origin in the value chain literature (Gereffi, 1999), it has been reconceptualized in the GPN literature through strategic coupling: firms and regions plugging into production networks governed by lead firms (Yeung, 2016) which can generate greater value, thereby increasing the prospects for value capture - i.e. resulting in economic development. There are, however, certain preconditions (economies of scale, the ability for localisation effect, and institutional capacity among firm and non-firm actors) before value creation, enhancement, and capture can take place (Coe and Yeung, 2015). But even here, firms and low- and middle-income regions face considerable challenges to having all these conditions in place before integration into global production networks can contribute to economic development (Foster et al., 2018).

\footnotetext{
${ }^{4}$ Workers had experience of both inbound and outbound calls.
} 
In buyer-driven production networks (e.g. fast-fashion garments and outsourced services), challenges for firms in low- and middle-income regions are: international competition, strong emphasis on standardized production, lack of technological know-how, and cost control. These can significantly affect the ability of small firms to achieve thicker forms of integration, i.e. flows of knowledge and upgrading (Murphy and Schindler, 2011). But what about labor?

This firm-centered approach in the GPN framework has not given adequate attention to labor in the production process for a number of years (Coe, 2013). However, there have been recent efforts to bring back the role of labor in the GPN analysis through the concept of "social upgrading", defined as the "process of improvement in the rights and entitlements of workers as social actors, which enhances the quality of their employment' (Barrientos et al. 2011: 324). Social upgrading includes both measurable standards (types of contracts, working hours, wages, social protection, etc.) and enabling rights (freedom of association, collective bargaining, non-discrimination in the workplace) (Barrientos et al., 2011; Milberg and Winkler, 2011). So, what is the link between economic and social upgrading?

In their study of the apparel, horticulture, mobile phone and tourism sectors in selected countries, Bernhardt and Milberg (2011) found that with the exception of the tourism sector, social upgrading is observed when economic upgrading takes place. Several other studies have pointed out that economic upgrading has variable impacts on the social upgrading of workers (Barrientos et_al.2_2016;_Rossi,_2013). For example, Rossi's (2013) study on the Moroccan garment industry demonstrated that process upgrading among supplier firms resulted in improvements in measurable standards among workers, but not necessarily their enabling rights. While functional upgrading (moving towards design, development, costing, packaging, marketing, and logistics) resulted in higher value generation for firms, workers experienced mixed outcomes. Regular workers experienced an improvement in measurable standards, but irregular workers earned lower wages, had temporary contracts, and more importantly were discriminated against on the factory floor while regular workers enjoyed higher degree of respect. Also, in buyer-driven production networks, like the fast-fashion garment industry (Brooks, 2015) and the outsourced services sector (Fernandez-Stark et al., 2011) the demand from lead firms for certain types of business models and standards can affect the ability of suppliers to provide quality products and maintain labor standards.

Case studies drawn from the African continent in horticulture (Baglioni, 2018) and the tourism sector (Christian, 2016) also suggest that the link between economic upgrading and social upgrading is not straightforward. Therefore, there is a need to pay considerable attention to the possibility of social downgrading (Goger et al., 2014). This is of particular importance for South Africa, where the legacy of apartheid and neoliberalism have created a highly unequal society and high levels of unemployment.

To understand the link between economic and social upgrading in the South African BPO industry, we first examine economic upgrading trajectories in outsourcing in South Africa (section 3). Although some literature exists on outsourcing in Africa, it is mainly focused on wider industrial strategies for economic development (Beerepoot and and_R___ssi,_2016), with relatively little emphasis on labor issues (notable exceptions are Benner, 2006; Benner et al., 2007). Using a survey of outsourcing firms' managers, Benner's (2006) study suggested that only a few firms in South Africa are experiencing process upgrading. Yet, a discussion of its impacts on workers - from the workers' perspective-was not the primary focus of Benner's study.

Furthermore, labor conditions, in the BPO industry globally, are largely informed by research in well-established locations such as India and the UK (Taylor and Bain 2005; Woodcock, 
2016) with less attention being paid to newly emerging locations like South Africa. Without knowing about the experiences of workers, development as understood through the process of 'economic upgrading' is not necessarily sufficient to support an improvement in labor conditions. In fact, Selwyn (2018) has argued that integration into global production networks and value chains can lead to new forms of worker poverty and exploitation. Thus, in section 4 , we reconceptualize various attributes of social upgrading through the job quality literature to show how economic upgrading can lead to both social upgrading and downgrading of workers. We now discuss the economic upgrading trajectories in the South African outsourcing industry.

\section{Economic Upgrading Trajectories in the South African Outsourcing Industry}

In 2012, the information and communications technology (ICT) sector in South Africa contributed roughly US\$ 7.5 billion to the South African economy. It made up $2.9 \%$ of the gross domestic product of the country, slightly higher than the agriculture sector but less than the tourism sector (Statistics South Africa, 2017). While an industry breakdown within the ICT sector is unavailable, it is estimated that the South African BPO industry earned revenues of US\$ 1.3 billion in 2012 (Frost and Sullivan, 2012). The South African BPO market is still domestically-oriented despite recent increases in international/offshore operations. ${ }^{5}$ In other words, a majority of the workers employed (whether employed by the local or foreign firms) in the industry are serving domestic customers (BPESA, 2018). The majority of the service providers are heavily concentrated around Johannesburg, Cape Town, and Durban, reflecting the urbanized geography of the information economy (Graham, 2002). ${ }^{6}$ Captive operations - either in-house or owned and managed by the parent firmaccount for $64.1 \%$ of the South African BPO market and $35.9 \%$ are outsourced operations run by a third-party firm for the main client. In terms of the industries served, financial services account for $50 \%$ of the total market, followed by telecoms $(19.1 \%)$, retail $(11.3 \%)$, transport (4.4\%) and IT (3\%), a trend noted in an earlier survey on the South African BPO industry (Benner et al., 2007). The UK market accounts for $67 \%$ of the offshore business, followed by Australia (21.5\%), Germany (1.9\%), the US (1.2\%) and others (7.3\%) (BPESA, 2018). ${ }^{7}$

Several political and economic factors explain these developments. The availability of a skilled workforce with competent English language skills, the quality of the infrastructure (electricity, internet, and transport), government support (incentives and tax breaks) and the rising costs of servicing clients from locations such as India and the Philippines have made South Africa an attractive location for offshore activities. Additionally, the declining value of the South African Rand (ZAR) over the last ten years is a critical factor in making South

\footnotetext{
${ }^{5}$ There are no clear estimates as to how many firms are foreign and how many are local in the South African outsourcing sector. So, the only way to understand the nature of the BPO industry in South Africa is through the number of jobs created, for which we have data from the private sector association, BPESA. Though this can be misleading since a large workforce in the domestic operations does not necessarily mean a higher revenue generation than offshore operations.

6 The South African BPO industry has been growing since the fall of Apartheid. Pandy and Rogerson (2012) and Benner (2006) have useful accounts of the growth of the BPO industry in South Africa and its changing regulatory environment. The DTI has recently launched a revised version of the incentives for BPO operations to be effective from January 01, 2019 in order to make outsourcing in South Africa more attractive (DTI, 2018).

7 Recent research has begun to discuss the role of global sourcing on domestic production networks and vice versa (Meng et al., 2013; Furusawa, 2017). However, in the outsourced services sector it is appropriate to think of global production networks, since these networks are highly international due to the location diversity of buyers, sellers and end-customers, and the footloose character of the industry.
} 
Africa competitive with other locations in terms of costs. As a result, South Africa, along with Mauritius, has experienced continuous upward growth both in terms of the number of firms and jobs generated (Benner and Rossi, 2016), with indications of economic upgrading taking place in the industry (Willcocks et al. 2015).

\section{Trajectories of economic upgrading}

There are different components in the outsourcing industry, based on value-added functions (Fernandez-Stark et al., 2011). At the bottom end, low value-added contact center operations provide firms with an easy entry into production networks, allowing them to participate in the global information economy. Firms can introduce advanced technologies, such as customer relationship management (CRM) tools, workforce management (WFM), predictive calling systems, universal queuing, voice biometrics and Six Sigma programmes, as part of process upgrading for executing customer services through both voice and non-voice technologies (e.g. telephone, email and webchat) to increase process efficiency and improve labor productivity. As part of product upgrading, firms can introduce new products that generate more value such as technical support, data management and analytics. Finally, firms can also upgrade their functions to high-value knowledge-intensive services such as investment banking, taxation, legal and consulting, as a result of inter-firm networks, strategic partnerships with lead firms for sharing knowledge, technology exchange, and research and development (Lechner and Dowling, 2010; Humphrey and Schmitz, 2002). However, the upgrading trajectories for firms vary geographically and are based on the nature of the enduser market, domestic firms' capabilities and their relationships with global lead firms (see Pavlinek and Zazalova, 2016), as well as with the region's position in the global production networks and linkages with the regional economies (Meng et al., 2013).

\section{Global lead firms and the growth of lower-end contact centers}

There are multiple upgrading trajectories opening up in the South African BPO industry. First, is the entry of foreign firms' offshore operations in South Africa. Some of the world's biggest outsourced services firms have set up contact center operations in the country, including Webhelp, WNS, Aegis, Capita, Genpact and Teleperformance, along with a host of regional shared service operations of global corporations like Amazon, Microsoft, British Petroleum, Shell and Lufthansa, who all have centers in South Africa for serving clients both in the region and abroad. South Africa acts as a gateway for international firms to expand their presence in other African countries. ${ }^{8}$ Amazon, the world's largest online retailer by total sales and market valuation, performs software development and provides seller support and technical operations from its Cape Town offices (including for Amazon Elastic Compute Cloud and a support team for Amazon Web Services) to service their client base in the European Union (Re-uters ${ }_{2}$ 2018).

The second upgrading trajectory is the lower-end BPO operations, including contact center services which have arguably witnessed the most significant growth both in the number of operations and jobs created. Voice-based contact center services have become the most dominant segment in the South African outsourcing industry, 'accounting for approximately $80 \%$ of all the outsourced services work in South Africa' (Interview, Official at Department of Trade and Industry (DTI), September 15, 2016). These services include inbound customer

\footnotetext{
${ }^{8}$ South Africa is the second largest African economy behind Nigeria, and is classified as a middle-income country by the World Bank. It is also a member of the BRICS bloc and the only African member of the G20.
} 
services $(51.3 \%)$, outbound sales $(10.8 \%)$, inbound sales $(16 \%)$, debt collection $(6.3 \%)$, and back-office processing (10.3\%) (BPESA 2018). ${ }^{9}$

Digital technologies are considered critical for delivering improved customer services and most firms we spoke to have some degree of process upgrading (Table 3), employing a mix of digital technologies (including CRM tools, automatic call distributors, predictive diallers, interactive voice response, and call recording systems) and communications channels such as social media, smartphone applications and webchat to deliver services (BPESA 2018). ${ }^{10}$

Table 3: Characteristics of firms interviewed

\begin{tabular}{|c|c|c|c|c|}
\hline Firm/Ownership & Nature of operations & $\begin{array}{l}\text { No. of } \\
\text { employees }\end{array}$ & $\begin{array}{l}\text { Industry specific } \\
\text { activities }\end{array}$ & Upgrading \\
\hline J1 Domestic & $\begin{array}{l}\text { Third-party contractor; } \\
\text { dependent on intermediaries } \\
\text { and lead firms. }\end{array}$ & $100-200$ & Retail; Telecommunication & Process \\
\hline J2 Domestic & $\begin{array}{l}\text { Outsourced services } \\
\text { provider. }\end{array}$ & $400-500$ & Finance; Government & $\begin{array}{l}\text { Process; } \\
\text { Product }\end{array}$ \\
\hline J3 Domestic & $\begin{array}{l}\text { Third-party contractor; } \\
\text { dependent on intermediaries. }\end{array}$ & $<100$ & Telecommunication & Now defunct \\
\hline J4 International & $\begin{array}{l}\text { Lead firm with global } \\
\text { operations. }\end{array}$ & $4,000^{*}$ & Multiple & $\begin{array}{l}\text { Process; } \\
\text { Functional }\end{array}$ \\
\hline J5 Domestic & $\begin{array}{l}\text { Outsourced services } \\
\text { provider. }\end{array}$ & $<500$ & Multiple & $\begin{array}{l}\text { Process; } \\
\text { Functional }\end{array}$ \\
\hline J6 International & $\begin{array}{l}\text { Main client; running captive } \\
\text { contact center. }\end{array}$ & $500-600 *$ & Banking; Finance & Process \\
\hline J7 Domestic & $\begin{array}{l}\text { Outsourced services } \\
\text { provider. }\end{array}$ & $200-400$ & $\begin{array}{l}\text { Education, Finance, } \\
\text { Staffing, }\end{array}$ & Process \\
\hline
\end{tabular}

* in South Africa only

An international services provider, J4, with several office sites across South Africa, has reduced dependence on voice calls from nearly $75 \%$ in 2012 to $20 \%$ in 2016 for one of its UK clients. Their contracts for non-voice digital channels have also increased from $4 \%$ to $17.5 \%$ across all clients. As one of their officials put it:

You [providers] cannot get away from digital anymore. It is not a question of whether you do digital or not, it is a question of whether you are geared [for it or not]. If you do not have digital then you need a new proposition.

This digital transition is driven by firms' desire to improve customer experience and operational efficiencies, and as a result, their use of new customer relationship management (CRM) approaches to innovate their services delivery model and diversify into different segments within the industry. For example, a domestic firm (J5) offers a range of lower-end, on-demand customer services, including technical support and social media management, through multiple digital channels such as voice calls, automated interactive voice responses, webchat, and WhatsApp. Another local firm (J2), which runs contact centers for clients in the finance and banking sector within South Africa and other countries on the African continent, manages multiple campaigns from one room in their offices in Johannesburg. In one of their

\footnotetext{
${ }^{9}$ Telemarketing sales can be done in two ways: inbound (a customer calls the company for information or products) and outbound (an agent makes a call to the customer for products and services).

${ }^{10}$ The BPO firms we spoke to did not disclose the specifics of the software and other technologies they are using nor the suppliers of those technologies.
} 
campaigns for a fast-food restaurant, a team of five workers performs customer support services (including complaints, delivery queries, and payment processing) across the country.

Whereas process upgrading can improve the efficiency of production processes, functional upgrading involves acquiring new higher-value functions in order to increase overall chances for firms to capture more value (Humphrey and Schmitz, 2002). South Africa is already emerging as the location of choice for upselling and retention, legal process outsourcing, financial services, and even business consulting work (BPESA 2015). ${ }^{11}$ International firms are able to exploit South Africa's unique value propositions, which include a favourable time zone for UK-based clients, a cultural affinity with the UK, and a skilled workforce, to deliver niche high-value services. For example, J4 has recently started business and technology consulting, system integration, web development, data analytics, and workforce management for its UK clients. That said, functional upgrading is not wide-spread among local South African firms, largely due to a number of challenges they face in production networks.

\section{Barriers and challenges of upgrading}

Despite increasing uptake of digital technologies in Africa, there exist numerous barriers and challenges for small African firms in terms of the presence of international firms, governance, and standards for data and business (Foster et al., 2018). The rising interest of international firms in setting up offshore operations in South Africa, through acquisitions, inhouse captive operations, strategic partnerships with vendors and outsourcers, is driven by the liberalized environment supported by the South African government's two-pronged incentive programmes for offshore BPO operations. One is the 'base incentive' (based on the number of actual offshore jobs created), which provides international outsourcing firms with three years of operational expenditure to offset some of their costs with a view to narrowing the cost gap between South Africa and other destinations. The other is the bonus incentive for job creation in excess of 400 offshore jobs (DTI, n.d.). An official at DTI told us this bonus to be a sum of R108,000 (US\$ 7,854) per job created over a period of five years, in order to encourage companies to sustain those jobs. The same official said that from a government perspective the offshore sector is a priority for job creation, and they expect the domestic sector (which receives government-funded skills development training) to achieve organic growth on their own.

It is also known that lead firms can bring foreign direct investment, create linkages and spillovers of technology — allowing local firms to learn and adapt to global standards (Yeung, 2016). However, global lead firms often use acquisitions and mergers to curb the local competition in the market. The United Nations Conference on Trade and Development (UNCTAD) has considered acquisitions and mergers as anti-competitive business practices and wants these regulated (Qaqaya and Lipimile, 2008). According to one BPESA official, 'one of the problems local South African BPO firms are going to face in the future is the dominance of foreign firms'. Already in 2012, WNS, a global outsourcing firm headquartered in India, acquired the South African firm Fusion Outsourcing for US\$ 10 million (BPESA, 2012a) and Capita, a UK-based outsourcing firm, acquired the South African firm Full Circle in 2012 (BPESA, 2012b).

Furthermore, global lead firms adopt certain business standards and certifications (mostly voluntary) to ensure quality and data security, for example, the International Organization for

\footnotetext{
${ }^{11}$ Upselling refers to a company's strategy to get a customer to spend more by buying an upgraded or premium version of what is being purchased. Retention means keeping the customer with the company, often through customer loyalty initiatives.
} 
Standardization (ISO) certifications. Lynnette Morris, the Chair of the South African Technical Review Committee for the South African Business Standards revealed that some US firms like IBM and Microsoft are already using their own business standards. Some of these cost at least one million ZAR (almost US\$ 75,000) for South African firms to accredit themselves, in order to gain reputation and trust for securing new contracts.

As a result, some smaller domestic firms struggle to operate profitably in the face of competition from international firms, expensive certification costs for business standards, and their lack of capacity and market reputation to secure contracts. The now defunct 96-seat contact center firm in Johannesburg (J3) had an international telecommunications firm, with operations in South Africa, as their main client. The client had outsourced debt collection from its customers to an intermediary in Johannesburg, who had then sub-contracted it to J3. The owner of $\mathrm{J} 3$ claimed that the center shut down because it was becoming difficult to operate under the terms and conditions imposed by the international client. Being a smallscale entrepreneur, the owner of $\mathrm{J} 3$ was dependent upon intermediaries for work and did not have the reputation to find work directly from international clients. Eventually, all workers in his contact center lost their jobs.

Overall, it has to be mentioned here that economic upgrading in the outsourcing sector does not take place in a linear manner, i.e. from entry into the networks to product upgrading to functional upgrading - although this might seem to be logical, and makes business sense particularly for small and medium-scale firms. Firms can embark on non-sequential upgrading trajectories depending on their business links with global lead firms, their embeddedness in the domestic economy, and the governance challenge they face in production networks. These have implications for workers and their social upgrading. There is therefore a clear need to examine the consequences of economic upgrading on improvements in working conditions and labor standards, to which we now turn.

\section{The Link Between Economic and Social Upgrading: A Contradiction?}

The link between economic and social upgrading has been explored from a variety of perspectives (Barrientos et al., 2016; Knorringa and Pegler, 2006). In outsourcing, supplier firms come under immense pressure from lead firms to monitor and control every aspect of production (for work quality and data security), including labor processes, particularly in contact centers. Therefore, in this section, we explore whether the internationalisation of the contact center industry in South Africa is leading to social upgrading among workers.

The concept of social upgrading is derived from the Decent Work Agenda of the ILO (Barrientos et al., 2011), which itself is rooted in the quality of work literature (Green $\underline{2}_{2} \underline{0} \underline{0} \underline{6}$ ). Certain core elements of job quality such as autonomy at work, work-life balance, health and safety at work, voice and empowerment are related to both measurable standards and enabling rights, with various actors such as firms, the state, non-government organisations, labor unions, independent regulators, etc., playing a key role in influencing these. For example, control over working hours is a good indicator of autonomy at work which contributes to measurable standards (e.g. preventing unsociable working hours or long shifts at work), the presence of social safety nets reduces worker vulnerability, and the presence of unions prevents workplace discrimination and gives workers bargaining power to improve both the measurable standards (wages and social protection), and enabling rights (freedom of association and collective action). We focus on certain key variables of job quality in this article, including income and social welfare, working conditions, workplace monitoring, and collective bargaining power, to examine how different aspects of economic upgrading contribute to both the social upgrading and downgrading of workers. We argue that economic 
upgrading can lead to improvements in certain measurable labor standards, but not necessarily enabling rights.

\section{Social Upgrading: Income and Workplace Environment}

Formal sector employment can provide a great deal of importance and meaning to the lives of workers in South Africa who are facing a general lack of jobs and a social welfare system that is under considerable strain, due to government debt, neglect of welfare services such as education and health in favour of social grants or cash payments to beneficiaries, and a lack of monitoring and evaluation of welfare policies (Patel, 2015). Contact centers provide a good entry point into formal sector employment and are seen as a source of income, employment benefits, transport to and from work, and recreational facilities. A majority of the workers we spoke to came from impoverished areas of Johannesburg including Soweto, Alexandria and Tembisa. These areas are largely populated by black South Africans; the poorest racial group with significantly higher rates of unemployment than any other group in the country (Statistics South Africa, 2014). For more than half of our workers, the contact center job was their first formal sector employment opportunity, and some said it was their only available option for paid work. Workers who had been employed before in other jobs, such as retail, welding, painting and plumbing, described their income from contact center jobs as better than their previous work. However, payment models vary between contact centers.

Some contact centers have a commission-based income model or incentives based on performance, while others have a fixed monthly income and some even have hourly wages. We spoke to Wan, an agent from Merchants, a South African-based BPO firm (a subsidiary of Dimension Data Holdings, owned by Nippon Telegraph and Telephone, a Tokyo-based telecommunication giant). He was working on the sales and retention campaign of a South African telecom company. He was getting paid a rate of about ZAR 20 per hour (US\$ 7.84 at Purchasing Power Parity (PPP) levels) when he joined in January 2015. ${ }^{12}$ His working hours were flexible and varied regularly depending on the demand at the center and the needs of the client, which meant his income fluctuated as well. ${ }^{13}$

Only a few workers had a fixed salary. We spoke to Mwenga, an agent at the in-house contact center of the Standard Bank South Africa. He started as a temporary worker contracted through an employment agency in 2014, and in 2015, became permanent under the bank's payroll. He noted that the permanent contract brought a sense of security to his life. His current salary before taxes, ZAR 18,799 per month (US\$ 3,300 at PPP levels), was the highest among the workers we spoke to, while the minimum was ZAR 5,000 (US\$ 860 at PPP levels) for temporary workers on flexible contracts. ${ }^{14} \mathrm{He}$ also qualified for employment benefits like medical aid, which temporary staff are not entitled to. We asked the agents in our sample if they thought their income was fair. The majority of the workers said their income was unfair. Ash, the agent at J2, who earns ZAR 7,000 a month (US\$ 1,200 at PPP) said, 'for the work that we do and the amount of pressure or stress or abuse that we endure, I think we are grossly underpaid'. However, one inbound customer service agent at J4, whose

\footnotetext{
12 The national minimum wage was introduced on May 2018 in South Africa at ZAR 20 per hour (The Mail and Guardian, 2017).

${ }^{13}$ Contact centres recruit temporary workers on flexible contracts to work during high volume call times, since their main clients expect service providers to have more workers handling customer queries but not during other times when call volume is low.

${ }^{14}$ The latest report from BPESA shows that captive in-house contact centers (both domestic and international) have higher wages than outsourced third-party centers (BPESA, 2018), which often hire temporary workers through employment agencies on flexible contracts.
} 
average monthly income including performance-based commission was around ZAR 9,000 a month (US\$ 1,600 at PPP) - told us that his 'rate is fair because of the expenses that I have, responsibilities that I have, so, I do not complain. Perhaps, if I had five children, a wife and all those things, I would say it is not'.

Contact centers tended to offer a safe and healthy work environment. As part of process upgrading, firms invest in improved infrastructure and ICT tools, which influence working conditions (health and safety issues) inside the centers. These are also essential for securing contracts with international firms. However, there are no set standards that define the working environment of the workplace. Some of the firms we visited were air-conditioned workplaces, had expensive office furniture, canteens and leisure areas (Figure 1). Workers acknowledged the presence of recreational facilities, such as a gym and cafeteria, in contact centers to have a positive impact on their work, output and stress management. By comparison, many of these facilities are rarely available in other jobs such as in the retail and hospitality industry.

Figure 1: Working environment of two contact centers in Johannesburg.

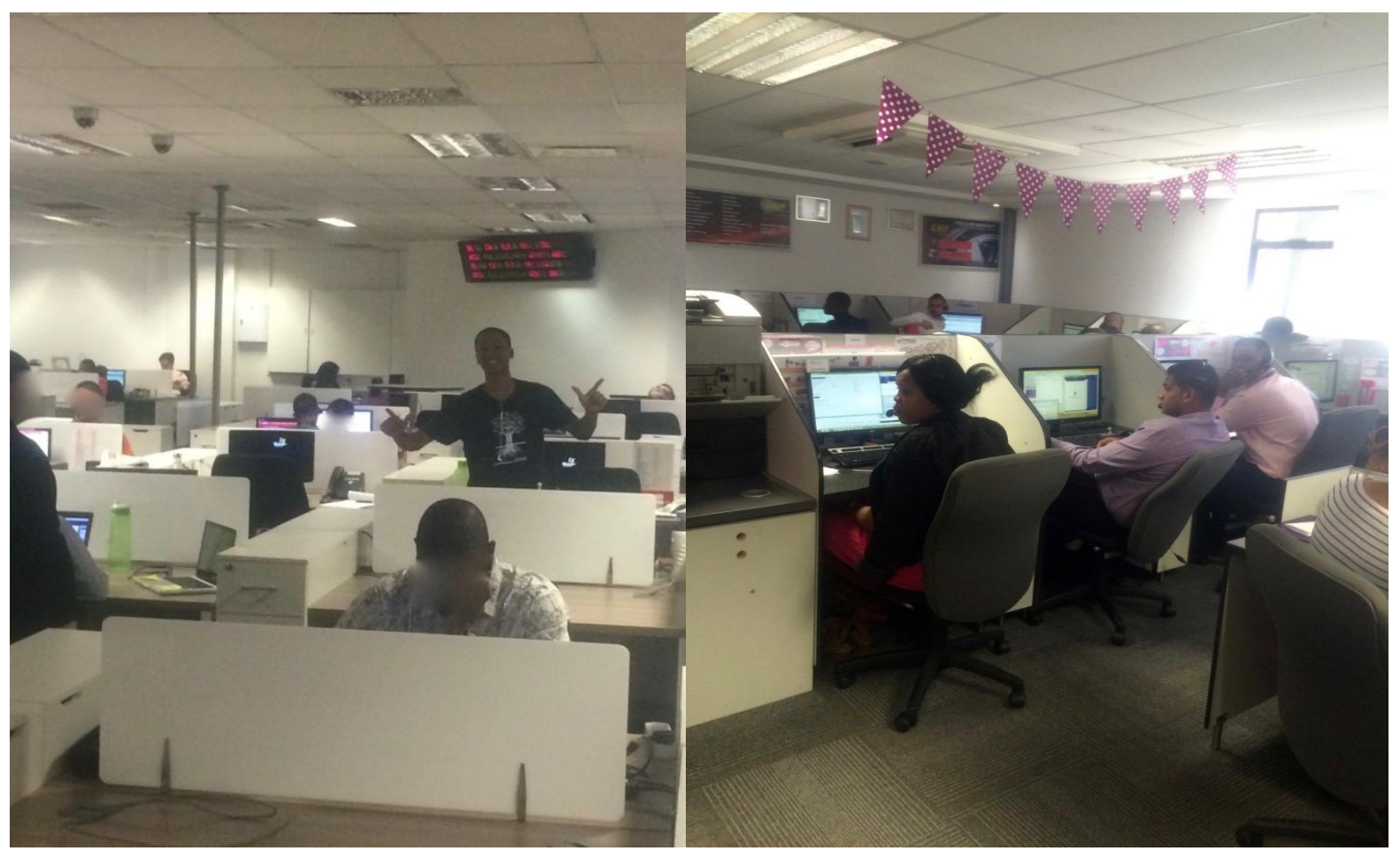

Challenges of economic upgrading on contact center jobs

Despite contact centers bringing formal sector jobs to the unemployed workforce, in the long run, economic upgrading will challenge the continuous growth of jobs in this industry in South Africa. The Head of the Client Service Center at J6, told us that labor and office space accounts for $60 \%$ of the operational cost of contact centers. He added that firms aim to move towards digital forms of customer service that direct customers to find answers to queries online, thereby reducing the dependence on a human workforce and lowering the operational costs. With automated channels becoming the norm in customer service, there will be less demand for human labor in contact centers.

Similarly, functional upgrading can also have consequences for future employment scenarios in the country. With high value-added activities emerging, such as ICT services and legal process outsourcing (LPO), the demand for skilled workers will increase. While it may help generate new types of jobs for a few, this can lead to the exclusion of a large section of the 


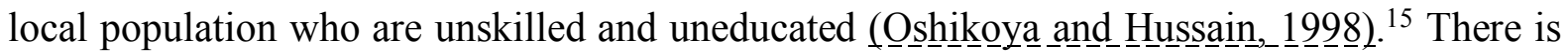
already a mismatch in the demand and supply of skilled workers in the local labor market, with the new workforce lacking the necessary technical and soft skills needed to secure a job (Pauw et al., 2008). It is here that the role of the state in education and training provision for the new workforce is critically important, to assist workers to find jobs in the local labor market.

The South African government has initiated various training programs in partnership with the domestic and international private sector, industry associations (BPESA), universities and training institutes, to equip workers with the necessary skills to gain employment in the outsourcing sector and beyond. For example, the Monyetla Programme of the South African Government had provided training to 3,000 entry-level BPO agents and 500 individuals at the supervisor and managerial levels by June 2011 (Infusion Knowledge Hub, 2013). Harambee, a youth employment accelerator programme in South Africa, received funds from the Rockefeller Foundation and the National Treasury of South Africa. According to one of their officials, Harambee screens and assesses job seekers, and trains them in soft skills such as punctuality, discipline, and positive attitude to work. However, very little is known about the impact of these types of training programmes on workers' employment. Given the high unemployment and slow job creation in the local labour market, the same official at Harambee said only one in ten people assessed by Harambee end up getting a job. According to the data supplied by Harambee during our fieldwork, roughly, $60 \%$ of workers trained by Harambee get a job in the retail and hospitality sector and only $4 \%$ end up in the BPO sector.

Finally, the link between the quantity and the quality of employment in contact centers is not necessarily positive (Taylor and Bain, 20 200 $\underline{0}$ ). The South African Government's drive to generate jobs in contact centers should, therefore, take into consideration the disconnect between the positive image of the contact center work and the harsh realities of labor processes that go in it. With this disconnect in mind, we now outline how these jobs can contribute to social downgrading among workers.

\section{Social Downgrading: Workplace Monitoring, and Lack of Collective Bargaining and Future Career Opportunities}

Contact centers operate strict workplace control methods that are technical, bureaucratic, and normative (Fleming and Sturdy, 2011) in order to ensure that firms offer better services and experiences for their customers. But quantification of worker performance and control over the labor process through updated technologies can contribute to the degradation of work, rather than an upgrading (Woodcock, 2016). In the following sections, we discuss the evidence of intense workplace monitoring, mental and physical stress, use of contingent employment practices, lack of collective bargaining, and a lack of career prospects among the South African BPO workforce.

\section{Workplace monitoring}

To understand how the introduction of new technologies affects working conditions in contact centers, we need to understand the core of the production process, particularly the calling system. The calling system connects workers to end customers to create a cycle of continuous calls in order to maximize the length of time workers are on calls, resulting in what Taylor and Bain (1999) referred to as 'an assembly line in the head'. Almost all kinds of worker activities and interaction with customers are monitored, stored, and analysed through the use of digital tools such as CRM software. Screens placed in the rooms display agents'

\footnotetext{
15 In other places also, like India, the growth of information technology (IT) activities are largely unsuited to the unskilled rural population (Anwar, 2014; Anwar and Carmody, 2016).
} 
daily performance and competence (see Figure 2) based on the number of calls answered, calls dropped, time spent on call, login efficiency, attendance, meeting daily quota, etc. These are often referred to as adherence levels. Ash, a contact center agent, described her experience:

In a call center, you are measured on keeping time [termed] schedule adherence. You are measured on how long you take your break...If you go over that time, you are penalized... How long you are actually spending on each line [call]. You get an average of that on a monthly basis. How much work you do is also measured.

Workers regularly complained that such workplace monitoring leads to demotivation and frustration, affecting both their personal and professional life. Ash said that once the shift is finished you do not leave some of those work skills and switch off. You take them home with you. She added that as a consequence of trying to finish her work tasks as quickly as possible (workers are under pressure to finish customer calls quickly; usually one to two minutes per call), she has started treating her child and the household work professionally, and it is creating a distance between her and the child.

Figure 2: Performance indicators on manual board (J3) and electronic display (at J6).

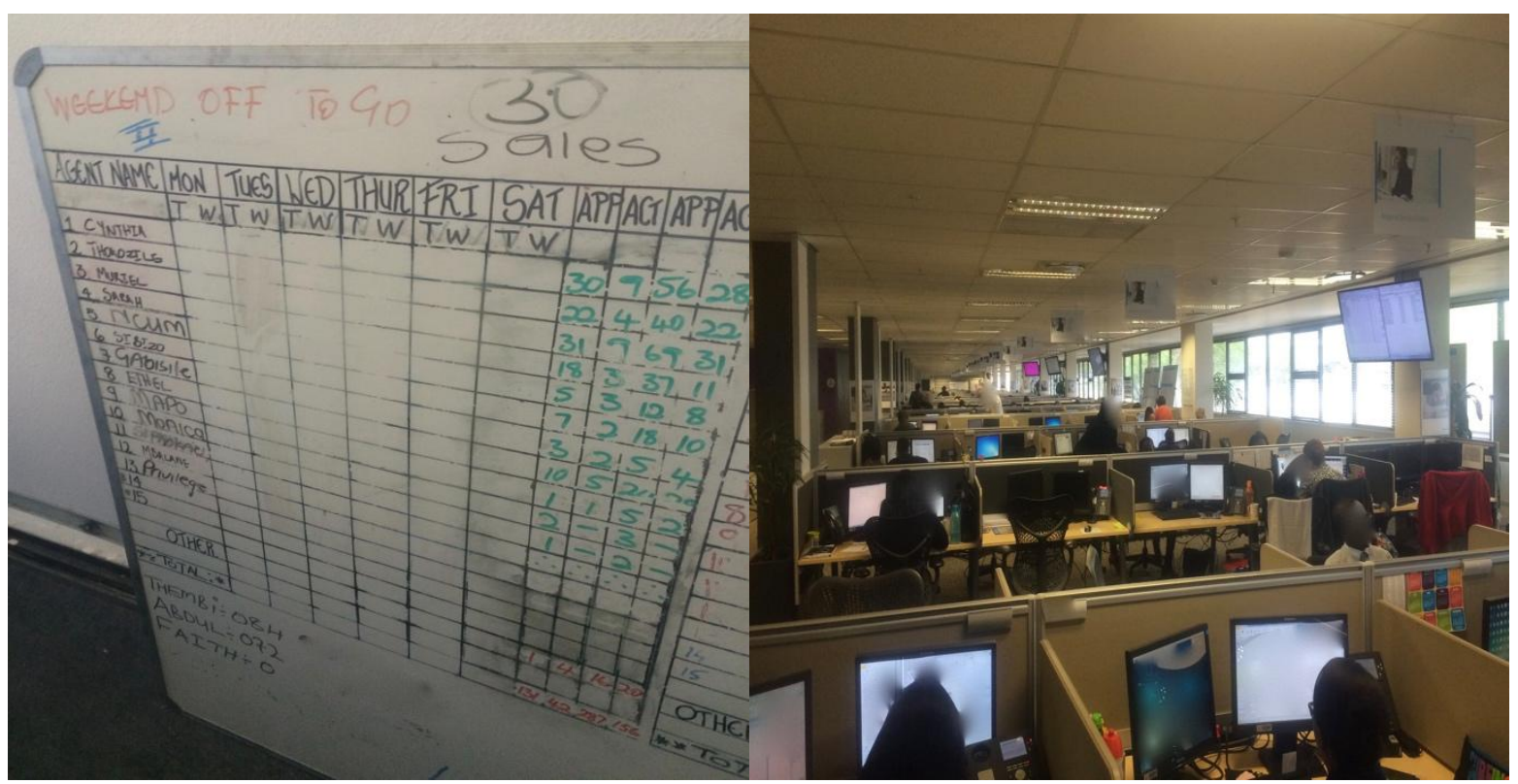

Financial gains to workers are offset by the loss of autonomy at work. One worker at J4 remarked that work 'does give you that bit of financial freedom, but it comes with sacrifices as well'. Workplace monitoring and strict control over labour processes can be tough and isolating for workers. One worker, Jabulile, an agent at J2, likened the center's working space to "packed sardines" due to the small size of the cubicles in which agents sit. Workers are also expected to multi-task with both voice and non-voice systems, which can be damaging both mentally and physically for workers. Some of the words used by agents to describe the mental and psychological impacts of this work were "stressful," "strenuous," "demotivating," and "frustrating." A worker, Thando at J1, told us that "I just felt like that I am not wanted in this environment so why go to work?'. Woodcock (2016, p. 55) has argued that new labor practices in contact centers reflect exploitation of the "minds" of workers, rather than a Fordist exploitation of their bodies. The increasing use of digital technologies to monitor and control every aspect of the labor process in contact centers are a contributory factor to this.

Contingent employment relations and lack of unionisation 
Whereas process upgrading in contact centers can lead to increased workplace control, functional upgrading can also contribute significantly to social downgrading. Integration with lead firms means that service providers adopt flexible employment structures (i.e. a mix of permanent and temporary workers) to keep costs down (Batt et al., 2009). Having a pool of permanent workers, who draw high salaries and employment benefits, with a mix of temporary and contractual workforce (with lower salaries and no employment benefits) helps service providers minimize their overall operational costs and yet remain flexible enough to scale up and down as per the demands of the main client (see Kalleberg, 2003). Firms (in outsourcing and beyond) are known to use a host of intermediaries, including labor agencies or employment contractors, to hire temporary workers, which opens up spaces for exploitation of workers (Barrientos, 2013). The role of these intermediaries in outsourcing is well known (James and Vira, 2012), and South African contact centers employ a high level of temporary contract workers (Benner, 2006). An industry expert noted that changes in labor regulations to encourage firms to offer permanent contracts to workers can hamper South African firms' flexibility and competitiveness (quoted in Willcocks et al., 2015, p. 72-73).

From the workers' perspective, this flexibility makes them vulnerable and subservient to the desires of employers. Workers feel threatened by employers since union representation in contact centers remains low in South Africa (Benner et al., 2007). Only one worker at J2 in our sample was a member of a labor union, and that was for a different union body to the Communications Workers Union (CWU), which is attempting to organize workers in contact centers in South Africa. According to a seven-year veteran of the industry, Tembi, workers are rarely organized in any contact centers in Johannesburg, not because unions would not be useful for improving working conditions and labor standards, particularly against wrongful termination of jobs, but because workers are unaware of the presence of unions for contact centers. He further added, 'because management knows workers are not unionized, they can actually say, okay, this is what you are going to be doing and either you are in or you are out. If you want to strike, the management just gives you a written warning and you are out. And then you cannot do anything'. A number of workers told us mistakes made by agents are often taken seriously and that after a couple of warnings, workers are fired without any arbitration or settlement. Wan said that it is common for workers to be fired at his contact center. In fact, he had his job terminated immediately over a complaint filed by a customer who was unhappy with a sale deal. Incidents like these can seriously affect workers' future career prospects, either within or outside the sector.

\section{Labor mobility and career prospects}

The opportunities for future employment expressed as labor mobility both within and across the sectors of an economy (that is, occupational mobility) is seen as key for labor agency (Vira and James, 2012) and hence for improved job quality. Contact center jobs in South Africa rarely allow for the internal progression of agents within a firm (Benner, 2006; Benner and Mane, 2011). This stands in contrast to experiences in India, where contact center workers have a greater chance of achieving upward labor mobility (James and Vira, 2012), due to a bigger national economy and its position as the world's leading player in outsourced services (Kleibert, 2015). Any comparisons between South Africa and India should, therefore, be drawn with caution.

We asked industry experts and firm managers what they thought about the career trajectories of contact center agents. An official at J4 said that these jobs are seen as a 'springboard for careers in other organisations, but not doing contact center work'. Some experts were sceptical of the long-term sustainability of these jobs. Jon Browning, the President of Global BPO Solutions, told us, 'BPO companies do not like attrition after one year, [but] they do not 
mind it after 2-3 years'. The attrition rates in this sector are certainly high, with BPESA suggesting it to be $30.9 \%$ annually among contact center workers in South Africa (BPESA, 2015). When our respondents were asked if they wanted to continue working at their firms in the future, all 16 said "no". They wanted, instead, to either move to a different firm in search of a higher income or to leave the sector. However, this is not easy. Job creation in South Africa has slowed down since 2000, and employment in the country is becoming more skill intensive (World Bank 2015). This has resulted in limited opportunities for the unskilled and semi-skilled workforce both in the formal and informal sectors. South African youth, particularly blacks, struggle to secure meaningful jobs, making contact center jobs an attractive entry point into the formal labor market, albeit without much hope for career progression. We encountered a few workers who were agents for more than five years and asked them why they were still working in the sector. One agent at $\mathrm{J} 2$ replied that they had no choice but to continue to work and hope working conditions would eventually improve. While there is no recent data on the racial composition of contact center workers in South Africa, data from 2007 suggests that blacks represent a significant proportion of contact center agents, but make up only $7 \%$ of managers, in comparison to whites who make up around $61 \%$ of managers (Benner et al., 2007).

In this section, we have considered several key aspects regarding the link between economic upgrading and social upgrading among contact centre workers. One is that different types of economic upgrading can have differential impacts on both the measurable standards and enabling rights of the workers. For example, whereas process upgrading can lead to improvements in certain measurable standards of contact center workers, particularly income generation and welfare services provisions, workers are enrolled in contingent employment relations through temporary and part-time contracts and lack autonomy at work. Similarly, both the process and functional upgrading can lead to improved work environment but can also increase workplace control, performance monitoring, unfair dismissal, exploitation, and health and safety concerns among agents. These are indicators of social downgrading among workers (see Table 4).

Table 4: Summarising the link between economic and social upgrading and downgrading in contact centres

\begin{tabular}{lll}
\hline & Social upgrading & Social downgrading \\
\cline { 2 - 3 } Economic Upgrading & Income generation & $\begin{array}{l}\text { Contingent employment } \\
\text { relations }\end{array}$ \\
\cline { 2 - 3 } & Private health care & Physical and mental stress \\
\cline { 2 - 3 } & $\begin{array}{l}\text { Improved work } \\
\text { environment }\end{array}$ & $\begin{array}{l}\text { Lack of autonomy at work; } \\
\text { lack of unionisation and } \\
\text { collective bargaining. }\end{array}$ \\
\cline { 2 - 3 } & Pension provision & $\begin{array}{l}\text { Lack of labor mobility and } \\
\text { career prospects }\end{array}$ \\
\hline
\end{tabular}

\section{Conclusions}

This article's main contributions are two-fold. First, we have demonstrated that the acquisition of South African outsourcing firms by international players is creating a consolidation at the top of domestic value chains, often to the disadvantage of local firms. Lead firms occupy dominant positions and exert power in production networks (e.g. over suppliers, costs, and standards) in order to manage production processes across a host of 
actors, resulting in value capture at the very top of the chain (Coe and Yeung, 2015). Unequal power relations in the network can lead to bigger firms benefiting, with smaller firms struggling to compete, especially in a neoliberal domestic environment like South Africa's. ${ }^{16}$

The case of the outsourcing industry in South Africa also shows that there are multiple trajectories of economic upgrading, yet there are crucial variations. Process upgrading is more common among small local firms in South Africa who are adopting new digital technologies for delivering better services and customer experience. But functional upgrading is difficult to achieve.

The second contribution of this article is to show that that different types of economic upgrading have differential impacts on the social upgrading of contact center workers. On the one hand, process upgrading can lead to improvements in certain measurable standards of contact center agents. For example, contact center jobs offer income earning opportunities for the unemployed poor in South Africa and expand social safety nets among these groups through employers' contribution to workers' pension and medical insurance: an indicator of social upgrading.

On the other hand, firms also adopt buyer-specific procedures and flexible employment structures that put pressure on both the measurable standards and enabling rights. In fact, both process and functional upgrading can also lead to increased workplace control, performance monitoring, unfair dismissals, exploitation, and health and safety concerns among agents: an indicator of social downgrading among workers. In the absence of job opportunities in other sectors and fewer prospects for career progression within the contact centers, workers may face a stagnation of their socio-economic fortunes. Finally, the lack of union activity in contact centers restricts workers' collective voice and ability to demand basic working rights, such as against unfair dismissals.

\section{Recommendations for policy makers}

In order to try to address these problems, the South African government needs to embrace a comprehensive economic development strategy (Benner, 2006). The South African government should offer preferential treatment for local firms through public services delivery contracts, support marketing campaigns abroad for the domestic sector, and develop a policy framework that ensures that the entry of big multinationals leads to technology and knowledge transfer. Finally, and perhaps most importantly, the South African government also needs to ensure that it has the institutional capacity to monitor working conditions in contact centers, in order to avoid the real potential for an erosion of working standards. By understanding some of these risks and setting minimum standards, regulators can ensure that the emerging knowledge economy can lead to more inclusive economic development.

\section{References}

Anwar, M.A. (2014). New modes of industrial manufacturing: India's experience with special economic zones. Bulletin of Geography: Socio-economic Series 24, 7-25.

Anwar, M.A. \& Carmody, P. (2016). Bringing globalization to the countryside: Special Economic Zones in India. Singapore Journal of Tropical Geography 37, 121-138.

Baglioni, E. (2018). Labour control and the labour question in global production networks: Exploitation and disciplining in Senegalese export horticulture. Journal of Economic Geography 18, 111-137.

\footnotetext{
${ }^{16}$ Seekings and Nattrass (2015) have argued that the post-Apartheid South Africa maintained and adopted some aspects of neoliberalism (trade liberalization and financialization) as well as public policies (welfare services delivery and strict regulation of the labor market) that were antithetical to neoliberalism.
} 
Barrientos, S. (2013). 'Labour chains': Analysing the role of labour contractors in global production networks. The Journal of Development Studies 49, 1058-1071.

Barrientos, S., Gereffi, G. \& Rossi, A. (2011). Economic and social upgrading in global production networks: A new paradigm for a changing world. International Labour Review, 150, 319-340.

Barrientos, S., Knorringa, P., Evers, B., Visser, M. \& Opondo, M. (2016). Shifting regional dynamics of global value chains: Implications for economic and social upgrading in African horticulture. Environment and Plannning A 48, 1266-1283.

Batt, R., Holman, D. \& Holtgrewe, U. (2009). The globalization of service work: Comparative institutional perspectives on call centers. International Labour Review, $62,453-488$.

Beekman, M., Bruinsma, F. \& Rietveld, P. (2004). ICT and the location of call centres: Regional and local patterns. VU University Amsterdam, Faculty of Economics, Business Administration and Econometrics.

Beerepoot, N. \& Keijser, C. (2015). The service outsourcing sector as driver of development: The expectations of Ghana's ICT for accelerated development programme. Tijdschrift voor economische en sociale geografie 106, 556-569.

Benner, C. (2006). 'South Africa on-call': Information technology and labour market restructuring in South African call centres. Regional Studies 40, 1025-1040.

Benner, C., Lewis, C. \& Omar, R. (2007). The South African call centre industry: A study of strategy, human resource practices and performance. URL https://www.wits.ac.za/media/migration/files/cs-38933-fix/migrated-pdf/pdfs5/South\%20Africa\%20GCC\%20Report.pdf (accessed 22.11.17).

Benner, C. \& Mane, F. (2011). From internal to network labor markets? Insights on new promotion processes from the call center industry. Industrial Relations: A Journal of Economy and Society 50, 323-353.

Benner, C. \& Rossi, J., (2016). An island off the west coast of Australia: Multiplex geography and the growth of transnational telemediated service work in Mauritius, in: Mirchandani, K. \& Poster, W. (Eds.), Borders in Service: Enactments of Nationhood in Transnational Call Centers. Toronto, University of Toronto Press.

Bernhardt, T. \& Milberg, W. (2011). Does economic upgrading generate social upgrading? Insights from the horticulture, apparel, mobile phones and tourism sectors. Capturing the Gains: University of Manchester, Manchester.

BPESA (2018). South Africa business process management: key indicator report 2018. $B P E S A$, Johannesburg.

BPESA (2015). South Africa business process services: key indicator report 2015. BPESA, Johannesburg.

BPESA (2012a). WNS acquires SA based Fusion Outsourcing for $£ 10$ million, BPESA. URL http://www.bpesa.org.za/2012/07/05/wns-acquires-sa-based-fusion-outsourcing-for10-million/ (accessed 31.3.16).

BPESA (2012b). Leading UK Outsourcer Capita acquires Full Circle. BPESA, Johannesburg.

Brooks, A. (2015). Clothing poverty: The hidden world of fast fashion and second-hand clothes. London, Zed Books. 
Christian, M. (2016). Tourism global production networks and uneven social upgrading in Kenya and Uganda. Tourism Geographies 18, 38-58.

Coe, N. (2013). Geographies of production III: Making space for labour. Progress in Human Geography 37, 271-284.

Coe, N., Dicken, P. \& Hess, M. (2008). Global production networks: Realizing the potential. Journal of Economic Geography 8, 271-295.

Coe, N. \& Yeung, H.W.C. (2015). Global production networks: Theorizing economic development in an interconnected world, Oxford, Oxford University Press.

DTI (2018) Global Business Service Incentive 2018, DTI, Pretoria

DTI (2013). Industrial policy action plan: Economic sectors and employment cluster. DTI, Pretoria.

DTI (2005). Business process outsourcing and offshoring: sector development strategy. DTI, Pretoria.

DTI (n.d). BPS: Programme Guidelines. DTI, Pretoria.

Fernandez-Stark, K., Bamber, P. \& Gereffi, G. (2011). The offshore services global value chain economic upgrading and workforce development. Duke Centre on Globalization, Governance and Competitiveness.

Fleming, P. \& Sturdy, A. (2011). Being yourself' in the electronic sweatshop: New forms of normative control. Human Relations 64, 177-200.

Foster, C., Graham, M., Mann, L., Waema, T. \& Friederici, N. (2018). Digital control in value chains: challenges of connectivity for East African firms. Economic Geography 94, 68-86.

Frost and Sullivan (2012). Demand analysis of the bpo and contact centre market within South African financial and retail sectors. New York, Frost and Sullivan.

Furusawa, T., Inui, T., Ito, K., Tang, H., 2017. Global Sourcing and Domestic Production Networks. CESifo Working Paper Series 6658, CESifo Group Munich.

Gereffi, G. (2005). The global economy: Organization, governance and development, in: The Handbook of Economic Sociology. Princeton, Princeton University Press, pp. 160182.

Gereffi, G. (1999). International trade and industrial upgrading in the apparel commodity chain. Journal of International Relations 48, 37-70.

Goger, A., Hull, A., Barrientos, S., Gereffi, G. \& Godfrey, S. (2014). Capturing the gains in Africa: Making the most of global value chain participation. Manchester, University of Manchester.

Graham, S. (2002). Bridging urban digital divides? Urban polarisation and information and communications technologies. Urban Studies 39, 33-56.

Green, F. (2006). Demanding work: the paradox of job quality in the affluent economy. Princeton, Princeton University Press.

Henderson, J., Dicken, P., Hess, M., Coe, N. \& Yeung, H.W.C. (2002). Global production networks and the analysis of economic development. Review of International Political Economy 9, 436-464. 
Humphrey, J. \& Schmitz, H. (2002). How does insertion in global value chains affect upgrading in industrial clusters? Regional Studies 36, 1017-1027.

Infusion Knowledge Hub. (2013). External evaluation of the Monyetla Work Readiness Programme- Phase 2. The Business Trust, Johannesburg.

James, A. \& Vira, B. (2012). Labour geographies of India's new service economy. Journal of Economic Geography 12, 841-875.

Kalleberg, A. (2003). Flexible firms and labor market segmentation: Effects of workplace restructuring on jobs and workers. Work and Occupations 30, 154-175.

Kleibert, J. (2015). Expanding global production networks: The emergence, evolution and developmental impact of the offshore service sector in the Philippines. Ph.D Thesis, University of Amsterdam.

Knorringa, P. \& Pegler, L. (2006). Globalisation, firm upgrading and impacts on labour. Tijdschrift voor Economische en Sociale Geografie 97, 470-479.

Lechner, C., \& Dowling, M. (2003). Firm networks: External relationships as sources for the growth and competitiveness of entrepreneurial firms. Entrepreneurship \& Regional Development $15,1-26$.

Meng, B., Wang, Z., Koopman, R., 2013. How are Global Value Chains Fragmented and Extended in China's Domestic Production Networks? IDE Discussion Papers 424.

Milberg, W. \& Winkler, D. (2011). Economic and social upgrading in global production networks: Problems of theory and measurement. International Labour Review, 150, 341-365.

Murphy, J. \& Schindler, S. (2011). Globalizing development in Bolivia? Alternative networks and value-capture challenges in the wood products industry. Journal of Economic Geography, 11, 61-85.

Oshikoya, T. \& Hussain, N. (1998). Information technology and the challenge of economic development in Africa. African Development Review 10, 100-133.

Pauw, K., Oosthuizen, M. \& Westhuizen, C. D. (2008). Graduate unemployment in the face of skills shortages: A labour market paradox. South African Journal of Economics 76, $45-57$.

Pandy, W., Rogerson, C., 2012. The Economic Geography of South Africa's Call Centre Industry. Urban Forum 23, 23-42. https://doi.org/10.1007/s12132-012-9142-4

Pandy, W. \& Rogerson, C. (2014). South Africa's call centre industry: The emerging challenges of a growing destination in the Global South. Mediterranean Journal of Social Sciences 5, 208.

Patel, L. (2015). Social Welfare and Social Development, 2nd ed. Oxford; New York, Oxford University Press.

Pavlínek, P., Žížalová, P., (2016). Linkages and spillovers in global production networks: firm-level analysis of the Czech automotive industry. J Econ Geogr 16, 331-363. https://doi.org/10.1093/jeg/lbu041

Qaqaya, H. \& Lipimile, G. (2008). The effects of anti-competitive business practices on developing countries and their development prospects. UNCTAD, Geneva.

Reuters. (2108). Amazon expands in Cape Town, stepping up cloud rivalry with Microsoft, Reuters, URL https://www.reuters.com/article/us-amazon-com-safrica/amazon- 
expands-in-cape-town-stepping-up-cloud-rivalry-with-microsoft-idUSKBN1KF0UR (accessed 11.12.18).

Rossi, A. (2013). Does economic upgrading lead to social upgrading in global production networks? Evidence from Morocco. World Development 46, 223-233.

Seekings, J. \& Nattrass, N. (2015). Policy, politics and poverty in South Africa. Palgrave Macmillan, Basingstoke.

Selwyn, B. (2018). Poverty chains and global capitalism. Competition \& Change. Online First https://doi.org/10.1177/1024529418809067

Statistics South Africa. (2014). Employment, unemployment, skills and economic growth: An exploration of household survey evidence on skills development and unemployment between 1994 and 2014. Government of South Africa, Pretoria

Statistics South Africa. (2017). Information and communication technology satellite account for South Africa: 2013 and 2014 (No. 04-07-01). Government of South Africa, Pretoria.

Taylor, P. \& Bain, P. (2005). 'India calling to the far away towns': The call centre labour process and globalization. Work Employment Society 19, 261-282.

Taylor, P. \& Bain, P. (1999). 'An assembly line in the head': Work and employee relations in the call centre. Industrial Relations Journal 30, 101-117.

The Mail and Guardian, (2017). Ramaphosa signs minimum wage agreement of R20/h, URL http://mg.co.za/article/2017-02-08-ramaphosa-signs-national-minimum-wageagreement-of-r20h/ (accessed 2.23.17).

Vira, B. \& James, A. (2012). Building cross-sector careers in India's new service economy? Tracking former call centre agents in the national capital region. Development and Change 43, 449-479.

Willcocks, L., Lacity, M., \& Craig, A. (2015). South Africa's BPO service advantage: Becoming strategic in the global marketplace, Basingstoke, Palgrave Macmillan.

Woodcock, J. (2016). Working the phone: Control and resistance in call centres. London, Pluto Press.

World Bank (2015). South Africa economic update: Jobs and South Africa's changing demographics. Working Paper Issue No. 7. Washington D.C.: World Bank Group. http://documents.worldbank.org/curated/en/479161467998767997/South-Africaeconomic-update-jobs-and-South-Africa-s-changing-demographics.

Yeung, H.W. (2016). Strategic Coupling: East Asian industrial transformation in the new global economy, Ithaca, NY, Cornell University Press. 